\title{
Evaluation of different (bollworms) infestation on Bt and Non-Bt cotton cultivars
}

\author{
Mujahid Niaz Akhtar ${ }^{*}$, Azam Ali $^{1}$, Ahmad Ali $^{2}$ and Amjad Farooq ${ }^{1}$ \\ 1. Institute of Pure and Applied Biology, Department of Zoology, Bahauddin Zakariya University Multan-Pakistan \\ 2. Department of Zoology, Islamia University Bahawal Pur-Pakistan \\ *Corresponding author's email: mujahidniaz81@ gmail.com \\ Citation \\ Mujahid Niaz Akhtar, Azam Ali, Ahmad Ali, and Amjad Farooq. Evaluation of different (bollworms) infestation on \\ Bt and Non-Bt cotton cultivars. Pure and Applied Biology. Vol. 9, Issue 3, pp1873-1881. \\ http://dx.doi.org/10.19045/bspab.2020.90200
}

\begin{tabular}{llll}
\hline \hline Received: 01/02/2020 & Revised: 25/04/2020 & Accepted: 04/05/2020 & Online First: 19/05/2020 \\
\hline
\end{tabular}

\section{Abstract}

The objective of the present study was to investigate the effect of chewing pests on Bt and Non-Bt cotton varieties in Southern Punjab (Pakistan). Five cotton varieties (One NIAB Non-Bt and four Bt varieties viz. IUB-33, MNH-988, Lalazar, and Sitara-009) were grown in four regions (Multan, Khanewal, Muzaffar Garh and Kabirwala). These cotton varieties were surveyed for the collection of data on different chewing pests (American, Pink, and Spotted bollworms) populations. The eggs and adult counts were calculated from April 2014 to October 2016. It was found that NIAB Non-Bt cotton has resulted in a larger number of chewing worms and eggs as compared to Bt varieties. Bt cotton showed significantly higher resistance than Non-Bt variety against chewing bollworms. It may be due to a lesser number of adults and eggs of these bollworms. However, it was estimated that these varieties were also affected by the climatic conditions of southern Punjab in Pakistan. Also, Non-Bt cotton varieties showed poor Host plant susceptibility index (HPSI) as compared to Bt varieties for all four sites. Host plant susceptibility index (HPSI) for Non-Bt cotton variety was 47.5, 40.59, and 25.1, on the other hand (HPSI) for Bt varieties were 90.18, 94.81 and 97.82 respectively for years 2014-2016. Therefore, it was suggested that the Bt cotton varieties are better than Non-Bt cotton varieties due to greater resistance against chewing bollworms.

Keywords: Bt cotton; Chewing worms; Climate; HPSI (Host Plant Susceptibility Index); Non-Bt cotton; Resistance

\section{Introduction}

Cotton is an important economic crop recently in this modern world. Cotton fiber demand increased day by day. It is the need of the hour that there must be an increased yield of cotton to meet the need of this fruitful crop product. There are different means by which the yield is minimized due to the different insects' pests [1]. Pests are commonly found agents that cause great damage to cotton. Chewing worms play a major role among many insect pests. The $\mathrm{Bt}$ cotton varieties have been developed that contain genetic resistance against different pests. Transgenic cotton or the Bacillus thuringiensis Berliner (Bt) has genes coding for toxins that provide resistance against lepidopteran borers. Due to this resistance the importance of $\mathrm{Bt}$ cotton could never be neglected here. Increased cotton yields have been obtained due to improved practices, greater experience with biotic varieties, and availability of higher quality inputs [2]. The 
impact of Bt cotton on costs and yield showed that the overall cost of production was slightly increased with a decrease in pest control cost [3]. Various types of pests that attack cotton have been included (American, pink, and spotted) bollworms, sucking pests like jassids, whitefly, thrips, and other aphids on both $\mathrm{Bt}$ and Non-Bt cotton varieties [4]. The army, pink and spotted bollworm have been found active from July to October but severely attack during September. Armyworm remained in the field after spray for a limited period. It was noted that newly hatched Helicoverpa Armigera (American bollworm) died when they eat leaves of the Bt cotton plants; no larvae reached the pupal stage, while in Non-Bt it has developed into a pupa. There is a significant decrease in the number of sprays for Bt cotton varieties as compared to Non-Bt most of the applications of the chemical have been used to control sucking pests; however, in case chewing pests spray has always been required to control American bollworm. Although Bt cotton plays a significant role to control bollworms partial foliar insecticide sprays have been required to control other bollworms that cause excessive damage in $\mathrm{Bt}$ fields [5]. In recent years, Bt cotton has been widely planted for selectively combating cotton bollworm, Helicoverpa armigera, Pectinophora gossypiella, and other lepidopteran pest species. As a result of reduced insecticide sprays, an increased abundance of natural enemies in Bt cotton fields efficiently prevents outbreaks of other pests such as cotton aphids [6]. Resistance produced by $\mathrm{Bt}$ cotton with the presence of the $\mathrm{Bt}$ gene is a tool to eradicate the bollworms population [7-10]. Another way to delay resistance is to insert a second toxin in addition to the first one (Cry1Ac) in the cotton genome. This gene pyramiding strategy (dual-gene Bt Cotton) could delay resistance provided the modes of action of these toxins differ [11, 12]. The pink bollworm infestation is negatively correlated with abiotic factors like temperature, humidity, and rains fall in both Bt and Non$\mathrm{Bt}$ cotton. However, Bt cotton was less attacked as compared to Non-Bt cotton varieties. A high level of pink bollworm infestation was observed during October [13]. In this study, we have investigated the effect of chewing bollworms on different cotton varieties i.e. Bt and Non-Bt. Major insects' pests of cotton-like as American, pink, and spotted bollworms were examined [14]. Their eggs and adult stages were counted from the sowing to the harvesting period. Keeping in view, five different varieties of four $\mathrm{Bt}$ and one Non-Bt cotton variety were selected.

\section{Materials and methods}

The present study was conducted from April 2014 to October 2016 to evaluate the resistance of $\mathrm{Bt}$ and Non-Bt cotton varieties against various chewing insect pests known as American, pink and spotted bollworms, which were abundant in a cotton crop in the different fields of the southern part of Punjab, Pakistan. Data were collected regarding egg counts and adult populations of these bollworms from five different cotton varieties from 2014-2016. Out of five one Non-Bt i.e. NIAB variety and four were $\mathrm{Bt}$ varieties that are Sitara-009, MNH-988, Lalazar, and IUB-33. These are the approved cotton varieties by (Punjab Seed Council) PSC Pakistan. Seeds were purchased from the local market at the rate of Rs.300/kg for $\mathrm{Bt}$ and $\mathrm{Rs} 250 / \mathrm{Kg}$ for non-Bt varieties. Before sowing, the seeds were treated with 95\% concentrated $\mathrm{H}_{2} \mathrm{SO}_{4}$ to remove the fuzz on cotton seeds. Raised beds were prepared at a distance of $2.5 \mathrm{ft}$ from each other. Two to three seeds were placed on these raised beds at a distance of $25 \mathrm{~cm}$ from each other. There was a collection of bolls from the cotton field such as 10 green bolls of 12 to 30 days of age from each cotton line. They were transported to the laboratory. After $24 \mathrm{~h}$, Pink bollworms 
(PBW) entrance holes were counted, then the 10 bolls from each cotton line were placed in a separate plastic box and incubated for $7 \mathrm{~d}$ at $27 \pm 2^{\circ} \mathrm{C}$, after incubation, bolls were cracked open and the number of live and dead larvae were counted. Pink bollworm mines that occurred in the internal carpel wall were counted and measured. Data about infested bolls by bollworms were noted after every ten days of interval Data were put to statistical analysis using one-way analysis of variance to know the significant effects of varieties. Means were separated using LSD (Least significant difference) test at 5\% level of significance.

Host plant susceptibility indices (HPSI) were also calculated using the following formula:

$$
H P S I=\frac{B-A}{B} \times 100
$$

Where; $A$ is insect population on the variety; $\mathrm{B}$ is the total insect population on all varieties.

\section{Results}

\section{Adult and egg count of Bollworms in Multan}

A comparison of means for the adult count of American Boll Worm (ABW) showed that NIAB Non-Bt had the highest count followed by MNH_988 and Sitara_009. IUB_33 had the least number of ABW. Adult count of Pink Bollworm (PBW) was also highest in NIAB Non-Bt and lowest in Sitara_009. The highest and lowest numbers of adult Spotted Boll Worm (SBW) were found in NIAB NonBt and Sitara_009 cotton varieties in Multan, respectively. A comparison of means of egg count of $\mathrm{ABW}$ found in cotton varieties of Multan showed that NIAB Non-Bt had the highest count while MNH_988 had the least number of eggs of ABW. The egg count of PBW was highest on NIAB Non-Bt and least on Sitara_009 in Multan. The egg count of SBW was found highest in NIAB Non-Bt and lowest in IUB_33 cotton varieties in Multan (Fig. 1, Table 1). Host plant susceptibility Index (HPSI) for Non-Bt cotton variety was $47.5,40.59$, and 25.1 , on the other hand
(HPSI) for Bt varieties were 90.18, 94.81 and 97.82 respectively for years 2014-2016.

Adult and egg count of Bollworms in Khanewal

Means for the number of adults $\mathrm{ABW}$ (American bollworm) present in different cotton varieties showed that NIAB Non-Bt had the highest and IUB_33 had the lowest figure, Highest mean numbers of adult of SBW were found in NIAB Non-Bt cotton verity. The least count of adult SBW was noted in IUB_33 cotton. Cotton variety Lalazar having the highest number of adults (PBW). The highest average number of eggs of $\mathrm{ABW}$ was present in NIAB Non-Bt. The lowest egg count of ABW was recorded in MNH_988 cotton variety. Lowest and high average egg counts of PBW of cotton in Khanewal were observed in MNH_988 \& NIAB Non-Bt cotton varieties. The average number of eggs of SBW was found highest and lowest in NIAB Non-Bt \& IUB_33 cotton varieties (Fig. 2, Table 2). Host plant susceptibility index (HPSI) for Non-Bt cotton variety was $84.84,28.81$, and 47.24 on the other hand (HPSI) for Bt varieties was 89.14, 91.06, and 94.59 respectively for years 20142016.

Adult and eggs counts of Bollworms in Muzaffar Garh

The average numbers of highest and lowest ABW adults were found in NIAB Non-Bt and IUB_33 respectively. The maximum average numbers of PBW adults were noted in NIAB Non-Bt followed by IUB_33 and MNH-988. The least average number of adult PBW was found in Sitara_009 cotton variety in Muzaffar Garh. The highest and least average counts for adult SBW were seen in NIAB Non-Bt and IUB_33 cotton varieties. The egg count of $\mathrm{ABW}$ was found to be highest in NIAB Non-Bt and lowest in Lalazar variety. In the case of PBW, the maximum and minimum egg counts for varieties were found respectively as NIAB Non-Bt and Sitara_009 varieties. The least and highest average 
number of eggs of SBW were present in the case of cotton varieties NIAB Non-Bt and MNH_988 respectively (Fig. 3, Table 3). Host plant susceptibility index (HPSI) for Non-Bt cotton was $65.42,22.77$, and 42.65 while for Bt cotton was 81.18, 96.3, and 87.08 respectively for years 2014-2016.

Adult and egg counts of Bollworms in Kabirwala

The highest number of $\mathrm{ABW}$ adult were counted in NIAB Non-Bt. The lowest numbers of $\mathrm{ABW}$ adults were seen in IUB_33 variety. In the case of PBW the highest and lowest counts of adults were observed NIAB Non-Bt and MNH_988 cotton varieties. The highest and least average numbers of adults of SBW in cotton fields of Kabirwala were noted in NIAB NonBt and MNH_988 varieties.

Highest and least mean numbers of eggs of ABW were respectively found in cotton varieties NIAB Non-Bt and Lalazar. The highest egg count of PBW on cotton was found in NIAB Non-Bt. On the other side, the least count of PBW eggs was noted in IUB_33 variety. Maximum and minimum numbers of eggs of SBW were found in NIAB Non-Bt and MH_988 cotton varieties (Fig. 4, Table 4). The host plant susceptibility index for Non-Bt cotton is 69.26, 35.06, and 55.24 while for Bt cotton is $88.05,92.38$, and 97.09 respectively for years $2014-2016$.

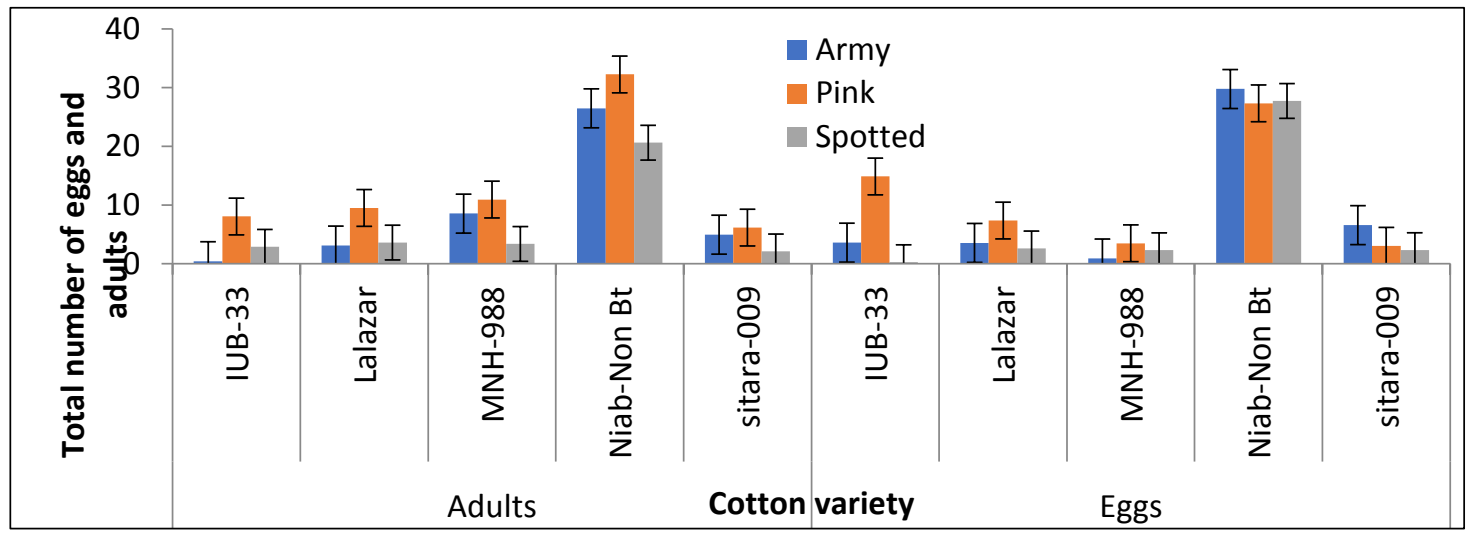

Figure 1. Total number of eggs and adults of different bollworms for different cotton varieties in Multan

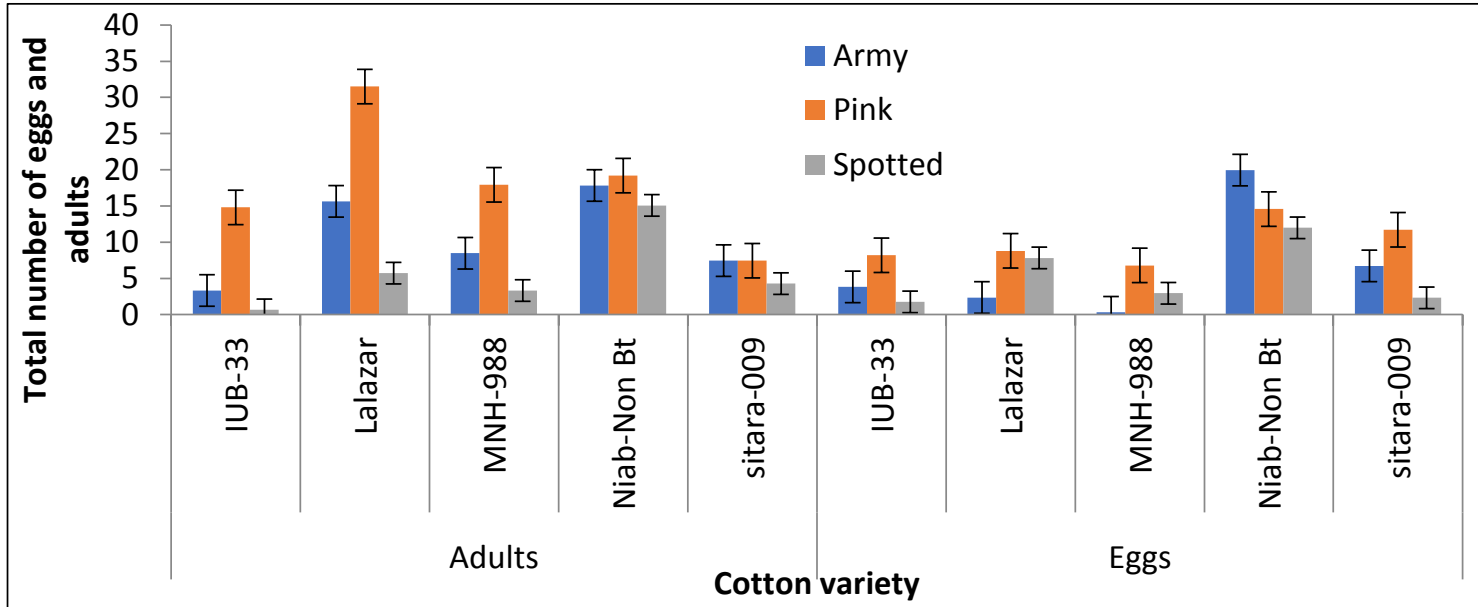

Figure 2. Total number of eggs and adults of different bollworms for different cotton varieties in Khanewal 
Pure Appl. Biol., 9(3): 1873-1881, September, 2020

http://dx.doi.org/10.19045/bspab.2020.90200

Table 1. Adults and eggs count of Bollworms in Multan

\begin{tabular}{|c|c|c|c|c|c|c|c|c|c|c|}
\hline \multirow{2}{*}{$\begin{array}{l}\text { Insect } \\
\text { Pests }\end{array}$} & \multicolumn{5}{|c|}{ Adults } & \multicolumn{5}{|c|}{ Eggs } \\
\hline & IUB-33 & Lalazar & MNH-988 & NIAB -Non Bt & sitara-009 & IUB-33 & Lalazar & MNH-988 & NIAB -Non Bt & sitara-009 \\
\hline Army & $0.424 \pm 0.042$ & $3.09 \pm 1.882$ & $8.535 \pm 3.543$ & $26.471 \pm 11.623$ & $4.948 \pm 1.999$ & $3.588 \pm 1.132$ & $3.54 \pm 1.131$ & $0.889 \pm 0.329$ & $29.763 \pm 11.124$ & $6.569 \pm 2.127$ \\
\hline Pink & $8.04 \pm 2.776$ & $9.5 \pm 3.875$ & $10.929 \pm 4.283$ & $32.246 \pm 16.958$ & $6.151 \pm 2.377$ & $14.859 \pm 6.582$ & $7.351 \pm 2.321$ & $3.478 \pm 1.422$ & $27.319 \pm 11.024$ & $3.049 \pm 1.501$ \\
\hline Spotted & $2.872 \pm 1.651$ & $3.602 \pm 1.982$ & $3.364 \pm 1.683$ & $20.618 \pm 9.972$ & $2.094 \pm 0.963$ & $0.251 \pm 0.074$ & $2.6 \pm 1.193$ & $2.289 \pm 1.174$ & $27.727 \pm 11.002$ & $2.305 \pm 1.173$ \\
\hline
\end{tabular}

Table 2. Adults and eggs count of Bollworms in Khanewal

\begin{tabular}{|c|c|c|c|c|c|c|c|c|c|c|}
\hline \multirow{2}{*}{$\begin{array}{l}\text { Insect } \\
\text { Pests }\end{array}$} & \multicolumn{5}{|c|}{ Adults } & \multicolumn{5}{|c|}{ Eggs } \\
\hline & IUB-33 & Lalazar & MNH-988 & NIAB Non Bt & sitara-009 & IUB-33 & Lalazar & MNH-988 & NIAB Non Bt & sitara-009 \\
\hline Army & $5.583 \pm 2.254$ & $8.741 \pm 2.135$ & $7.281 \pm 2.432$ & $14.678 \pm 6.234$ & $6.186 \pm 2.142$ & $2.336 \pm 1.032$ & $2.225 \pm 1.023$ & $7.669 \pm 2.236$ & $18.034 \pm 8.137$ & $3.828 \pm 1.246$ \\
\hline Pink & $17.526 \pm 8.257$ & $8.875 \pm 3.276$ & $14.208 \pm 5.277$ & $24.907 \pm 10.762$ & $4.764 \pm 2.167$ & $7.969 \pm 3.892$ & $2.239 \pm 1.091$ & $4.001 \pm 1.999$ & $25.715 \pm 11.738$ & $0.033 \pm 0.009$ \\
\hline Spotted & $1.1629 \pm 0.286$ & $1.8771 \pm 0.986$ & $2.0835 \pm 1.425$ & $9.4644 \pm 4.7867$ & $5.4486 \pm 2.793$ & $1.393 \pm 1,011$ & $0.838 \pm 0.011$ & $0.33 \pm 0.011$ & $20.568 \pm 10.116$ & $1.056 \pm 1.019$ \\
\hline
\end{tabular}

Table 3. Adults and eggs count of Bollworms in Muzaffargarh

\begin{tabular}{|c|c|c|c|c|c|c|c|c|c|c|}
\hline \multirow{2}{*}{$\begin{array}{l}\text { Insect } \\
\text { Pests }\end{array}$} & \multicolumn{5}{|c|}{ Adults } & \multicolumn{5}{|c|}{ Eggs } \\
\hline & IUB-33 & Lalazar & MNH-988 & NIAB Non Bt & sitara-009 & IUB-33 & Lalazar & MNH-988 & NIAB Non Bt & sitara-009 \\
\hline Army & $0.378 \pm 0.088$ & $5.41 \pm 2.458$ & $1.378 \pm 0.458$ & $26.298 \pm 11.883$ & $6.186 \pm 3.242$ & $2.492 \pm 1.436$ & $0.508 \pm 0.036$ & $1.683 \pm 0.457$ & $27.174 \pm 10.362$ & $10.27 \pm 4.433$ \\
\hline Pink & $10.173 \pm 4.092$ & $21.681 \pm 10.912$ & $5.729 \pm 2.022$ & $27.269 \pm 11.912$ & $15.046 \pm 7.092$ & $4.022 \pm 1.322$ & $5.847 \pm 2.343$ & $4.704 \pm 1.832$ & $29.181 \pm 11.342$ & $11.8 \pm 5.332$ \\
\hline Spotted & $0.305 \pm 0.168$ & $1.251 \pm 1.268$ & $0.251 \pm 0.199$ & $28.283 \pm 10.621$ & $13.171 \pm 6.167$ & $0.263 \pm 0.251$ & $0.944 \pm 0.986$ & $0.025 \pm 0.006$ & $30.293 \pm 12.563$ & $10.007 \pm 4.256$ \\
\hline
\end{tabular}

Table 4. Adults and eggs count of Bollworms in Kabirwala

\begin{tabular}{|c|c|c|c|c|c|c|c|c|c|c|}
\hline \multirow{2}{*}{$\begin{array}{c}\text { Insect } \\
\text { Pests }\end{array}$} & \multicolumn{5}{|c|}{ Adults } & \multicolumn{5}{|c|}{ Eggs } \\
\hline & IUB-33 & Lalazar & MNH-988 & NIAB Non Bt & sitara-009 & IUB-33 & Lalazar & MNH-988 & NIAB Non Bt & sitara-009 \\
\hline Army & $3.32 \pm 1.489$ & $15.638 \pm 7.657$ & $8.463 \pm 4.982$ & $17.829 \pm 7.879$ & $7.447 \pm 2.978$ & $3.814 \pm 1.168$ & $2.354 \pm 1.070$ & $0.306 \pm 0.068$ & $19.957 \pm 7.879$ & $6.719 \pm 2.978$ \\
\hline Pink & $14.798 \pm 5.928$ & $31.496 \pm 12.243$ & $17.925 \pm 8.628$ & $19.194 \pm 6.463$ & $7.433 \pm 5.672$ & $8.186 \pm 3.881$ & $8.805 \pm 3.999$ & $6.79 \pm 2.971$ & $14.567 \pm 6.463$ & $11.71 \pm 6.773$ \\
\hline Spotted & $0.648 \pm 0.140$ & $5.712 \pm 2.042$ & $3.315 \pm 1.162$ & $15.077 \pm 6.111$ & $4.26 \pm 1.173$ & $1.743 \pm 0.231$ & $7.822 \pm 3.312$ & $2.933 \pm 1.931$ & $11.981 \pm 5.672$ & $2.305 \pm 1.098$ \\
\hline
\end{tabular}




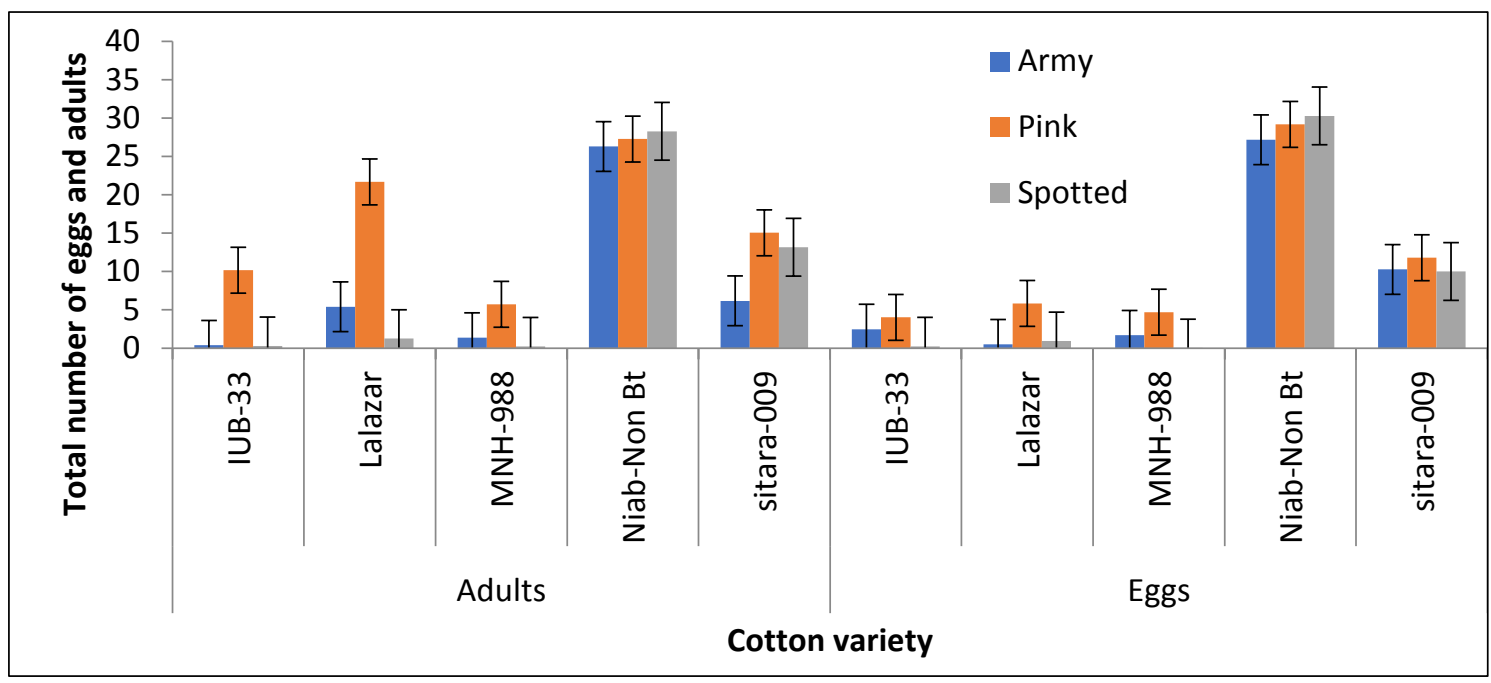

Figure 3. Total number of eggs and adults of different bollworms for different cotton varieties in Muzaffargarh

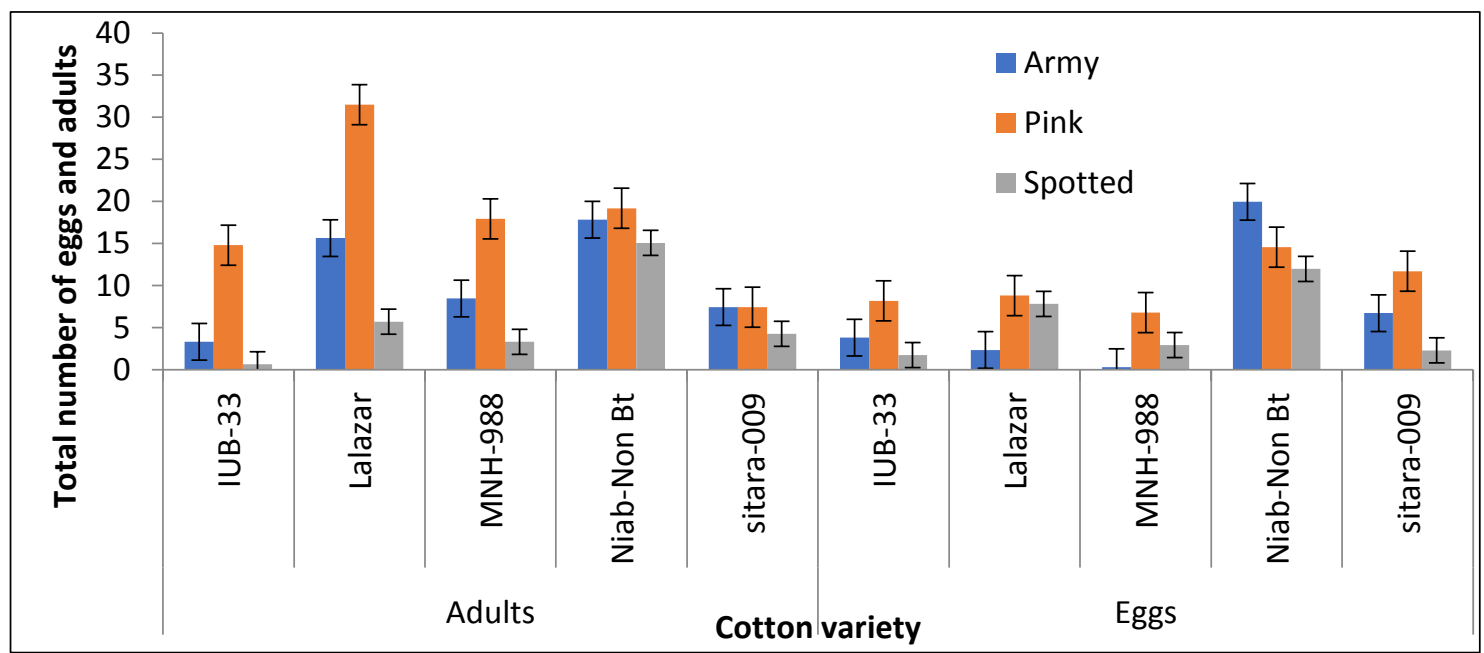

Figure 4. Total number of eggs and adults of different bollworms for different cotton varieties in Kabirwala

\section{Discussions}

Two important aspects of insect pests were noted during the study period related to their lives i.e. number of eggs and adult populations. It was noted that three kinds of bollworms were commonly present in cotton fields namely American, pink, and spotted bollworms. Different cotton varieties pose variable resistance to various insect pests. This variation in resistance is depicted in the form of the number of eggs and adults of insect pests found on the variety. The varietal differences thus become significant as some insect pests flourish well in the least resistant cotton variety while they could not do well on others. In most of the cases, bollworms (either American, pink, or spotted bollworm) egg and adult counts were higher on NIAB Non-Bt cotton. It seems that this variety is more prone to insect attack and showed the least resistance against them in the Multan region. One of the varieties (IUB-33) had the least number of eggs of $\mathrm{ABW}$, meant that it possessed the highest resistance against this worm and was comparatively better to grow in the area where there were more chances of 
ABW attack. In the case of Pink Bollworm highest resistance was observed in Sitara-009 cotton variety in Multan. Yearly and monthly effects produced a significantly different egg and adult counts showed their ample influence on insect pest dynamics. A surprising fact was that higher humidity and temperature dis favored PBW adults in Multan cotton fields. Moderate humidity, temperature, and wind speed ranges were more suitable for these worms. It meant that farmers should be more careful about PBW when temperature and humidity are lower and the variety is NIAB Non-Bt. Sitara-009 is more suitable under such circumstances where there are more chances of PBW attack. The increased humidity appeared to be destructive for eggs of PBW. The lower temperature was suitable for eggs of this worm. Adult counts of SBW in the cotton field of Multan presented that NIAB Non-Bt was the least resistant variety while Sitara009 showed the highest resistance against SBW. Yearly differences mostly depended on the population dynamics of insects and their predators. Higher egg counts hence would have been responsible for a larger number of adults as both variables are strongly correlated. There is no doubt that if the eggs were produced higher in number then adults' numbers will be more dependent upon the hatchability. Meteorological parameters such as temperature, humidity, and wind speed could not produce significant differences for eggs and adult counts of ABW for Multan cotton fields. This is because of their minor differences and narrow ranges for these parameters as the weather almost remained hot and humid during most of the year. A long-term study comprising of a decade or more perhaps could yield reasonable differences for insect populations. It looks that a hot humid environment was more favorable for the propagation of $\mathrm{ABW}$. It was observed that higher temperatures and humidity produced the highest number of eggs that ultimately turned into a higher number of adults of bollworms in the Multan cotton fields. In short, NIAB Non-Bt cotton variety was more prone to insect attack when there were higher temperatures and humidity and fast wind speed. This insect was found higher in numbers when humidity was lower and the temperature was slightly higher $\left(40^{\circ} \mathrm{C}\right)$ at moderate wind speed. Higher humidity and temperature were favorable conditions for laying of eggs for SBW which was depicted in the cotton fields in terms of higher egg count. Again, NIAB Non-Bt became less favorable variety for the area. The situation of egg and adult count of different bollworms found in cotton fields of Khanewal showed almost similar fashion as in Multan. The influential factors (period, variety) remained significant sources of variation for egg count and adult population of $\mathrm{ABW}$ on one side while environmental variables (temperature, humidity, and wind speed) appeared to be non-significant sources of variation for this dependent variable. Similar results were obtained for PBW and SBW. Both egg count and the number of adults of every worm type showed significant variation across years and months (period) during the study. Environmental factors could not produce significant differences in these variables (egg and adult counts) of PBW and SBW in the Khanewal region. The differences due to period (year and month) were due to changing insect and their population densities over time. Egg count depended upon the number of insects laying eggs, and how much eggs remained intact to hatch. Adult counts depended upon the hatchability of eggs and the number of larvae turning into adults and safety from the predators. American bollworm population at the beginning of the study (April 2014) was minimum which gradually increased became maximum in October 2014. It showed that the number of insects increased with the maturity of cotton. Bollworms population 
depends on cotton bolls to stay on, hence their presence is needed for insects. It means October is not a safe period for cotton bolls in Khanewal. Necessary control measures are needed to check the expanding ABW population during this month. Muzaffar Garh district is not very far away from Multan and the districts are separated by a riverine partition. Egg counts of $\mathrm{ABW}, \mathrm{PBW}$, and SBW significantly differed for the years and months within years. Yearly variation usually is affected by insect control program/pesticide sprays and cropping densities in and around the district. The differences in varieties depict their internal resistance against hose worms. Suitable environmental conditions also help the worm eggs to hatch into a new one. The influence of humidity, temperature, and wind speed being non-significant on egg counts of these worms (ABW, PBW, and SBW) indicated that egghead equal opportunity to hatch and multiply the insects on cotton crops in the region. Similarly, the average population of adults of these bollworms varied across years and months in this region. Yearly differences might depend upon insect population control and population dynamics. Cropping intensity might have affected this variable. One of the varieties of cotton (NIAB Non-Bt) was found to be the most favorite variety for the insects (ABW, PBW \& SBW). Maximum resistance against these worms was observed in IUB_33 cotton variety in Muzaffar Garh. It was apparent that farmers could have saved their crops from the attack of these bollworms by cropping IUB_33 cotton variety in this region. A similar pattern of effects was noted in Kabirwala. Years' had variable egg and adult counts of different bollworms (ABW, PBW \& SBW). Within years differences were also significant for egg counts. This is directly related to crop phenological stages, moth visiting these crops, and laying of eggs. Environmental factors were as usually of secondary importance as they could not have influenced egg counts. As regards the cotton varieties, NIAB Non-Bt variety bore the maximum number of eggs and adults of ABW, SBW, and PBW in Kabirwala. It showed that this cotton variety was least resistant against these insect pests. The cotton varieties IUB_33 and MNH_988 showed maximum resistance against adult $\mathrm{ABW}$, $\mathrm{PBW}$, and SBW respectively in this region. Moths of ABW, PBW, and SBW mostly visited and laid eggs on NIAB Non-Bt. The least number of eggs of $\mathrm{ABW}, \mathrm{PBW}$, and SBW were noted on Lalazar, IUB_33, and MNH_933 cotton varieties in the area showing maximum resistance against these pests. ABW and PBW loved moderate humidity and high temperature in this area. So, it was clear that farmers should avoid growing NIAB Non-Bt cotton in this region to save economic losses due to these bollworms. Many studies across the globe had already revealed similar results as found in the present research work in Southern Punjab, Pakistan. Significant correlations of environmental factors and insect pests have been reported [15-19]. Bt cotton has been declared as better in resistance against pests. Genetically modified cotton has shown remarkable resistance against some pests [20].

\section{Conclusion}

Present results indicated that $\mathrm{Bt}$ cotton varieties were better in performance than non-Bt. It is better to cultivate $\mathrm{Bt}$ varieties rather than Non-Bt to get an economic benefit.

\section{Authors' contributions}

Conceived and designed the experiments: $\mathrm{MN}$ Akhtar, Az Ali \& A Farooq, Performed the experiments: MN Akhtar \& AZ Ali, Analyzed the data: MN Akhtar, AH Ali, Contributed materials/ analysis/ tools: MN Akhtar \& AZ Ali, Wrote the paper: MN Akhtar \& AZ Ali.

\section{References}

1. Ozyigit II, Kahramanand MV, \& Ercan O (2007). Relation between explants age, total phenols and regeneration response in tissue 
cultured cotton (Gossypium hirsutum L.). Afr J of Biotechnol 6: 3-8.

2. Malik SN, Zia K, Ajmal M, Shoukat RF, Li S, Saeed M, Zafar J \& Shoukat RF (2018). Comparative efficacy of different insecticides and estimation of yield losses on Bt and Non Bt cotton for thrips, red cotton bug and dusky cotton bug. J of Entomol and Zool Stu 6(6): 505-512.

3. Naranjo SE (2011). Impacts of Bt Transgenic Cotton on Integrated Pest Management. $J$ of Agric and Food Chem 59: 5842-5851.

4. Sarwar M \& Sattar M (2016). An Analysis of Comparative Efficacies of Various Insecticides on the Densities of Important Insect Pests and the Natural Enemies of Cotton, Gossypium hirsutum L. Pak J of Zool 48(1): 131-136.

5. Kavitam B, Manisha M, Nazaneen S \& Nerendra K (2015). Impact of Climate Change on Insect Pests. Trends in Biosci 8(3): 597600.

6. Zhao JH, Ho P \& Azadi H (2011). Benefits of Bt cotton counterbalanced by secondary pests? Perceptions of ecological change in China. Environ Monit and Asses 173: 985994.

7. Caprio MA (1994). Bacillus thuringiensis gene deployment and resistance management in single- and multi-tactic environments. Biocont Sci and Technol 4: 487-497.

8. Gahan LJ, Gould F \& Heckel DG (2001). Identification of a gene associated with $\mathrm{Bt}$ resistance in Heliothis virescens. Sci 293(3): 857-860.

9. $\mathrm{Ru} \mathrm{LJ}$, Whao JZ \& Rui $\mathrm{CH}$ (2002). A simulation model for adaptation of cotton bollworm to transgenic Bt cotton in northern China. Acta Entomol Sinica 45: 153-159.

10. Vacher C, Bourguet D, Rousset F, Chevillon C \& Hochberg ME (2003). Modeling the spatial configuration of refuges for a sustainable control of pests: a case study of $\mathrm{Bt}$ cotton. J of Evolu Biol 16: 378-387.

11. Carriere Y, Ellers-Kirk C, Amanada L, Patin, Sims MA, Meyer S, Liu YB, Dennehy TJ, \& Tabashnik BE (2001). Overwintering Cost Associated with Resistance to Transgenic Cotton in the Pink Bollworm (Lepidoptera:
Gelechiidae). J of Econ Entomol 94(4): 935941.

12. Estela A, Escriche B \& Ferre' J (2004). Interaction of Bacillus thuringiensis toxins with larval mid gut binding sites of Helicoverpa armigera (Lepidoptera: Noctuidae). Appl Environ Microbiol 70: 1378-1384.

13. Khan BS, Afzal M \& Murtaza M A (2002). Effect of abiotic factors against the infestation of pink bollworm (pectinophora gossypiella) on different nectarid and nectariless cotton varieties under unsprayed conditions. Pak $J$ of Agric Sci 39(4): 338-340.

14. Akhtar MN \& Farooq A (2019). Environmental impact of bollworms infestation on cotton, Gossypium hirsutum. Pak J of Zool 51(6): 2099-210.

15. Ali MI, Ali RG, Luttrel S \& Young III (2006). Susceptibilities of Helicoverpa zea and Heliothis virescens (Lepidoptera: Noctuidae) Populations to Cry1Ac Insecticidal. J of Econ Entomol 99(1): 164-175.

16. Burd AD, Gould F, Bradley JR, Van Duyn J W \& Moar WJ (2003). Estimated Frequency of Non-recessive Bt Resistance Genes in Bollworm, Helicoverpa zea (Boddie) (Lepidoptera: Noctuidae) in Eastern North Carolina. J of Econ Entomol 96(1): 137-142.

17. Fitt GP, Mares CL, \& Llewellyn DJ (1994). Field evaluation and potential ecological impact of transgenic cottons (Gossypium hirsutum) in Australia. Biocont Sci and Technol 4: 535-548.

18. Gahan LJ, Gould F \& Heckel DG (2001). Identification of a gene associated with $\mathrm{Bt}$ resistance in Heliothis virescens. Sci 293(3): 857-860.

19. Ghafoor A, Hassan M, Alvi Z H \& Kousar S (2011). Impact of different varieties of stub cotton on population dynamics of whitefly at Faisal Abad, Pakistan. Pak J of Zool 43(1): 2528.

20.Benedict JH, Sachs ES, Altman OW, Ring OR, Stone TB \& Sims SR (1993). Impact of B Endotoxin-Producing Transgenic Cotton on Insect-Plant Interactions with Heliothis virescens and Helicoverpa zea (Lepidoptera: Noctuidae). Environ Entomol 22(1): 1-9. 